\section{LECTURES ON THE SCIENTIFIC BASIS OF MEDICINE \\ Volume II, 1952-53}

British Postgraduate Medical Federation. Pp. xi + 380, illustrated. London: The Athlone Press. 1954. 35s.

The nineteen lectures printed in this volume were chosen from a course arranged by the British Postgraduate Medical Federation during the winter, 1952-53. The lecturers were all eminent in their chosen fields and the wide choice of subjects provides a stimulating survey of advances in the knowledge of fundamental principles. Whereas the delivery of the various lectures varied in clarity and conciseness, the printed products are succinct, clear and make absorbing reading.

Physiological topics include parturition, the autonomic nervous system and the effects of gravity. Physicians as well as biochemists should refer to Dr. G. E. Dent's chromatographic studies of aminoacid metabolism, Professor R. H. S. Thompson's views on cholinesterases, the adrenocortical hormones by Professor G. F. Marrian, or Dr. A. Neuberger's account of Biochemical Genetics. The reviewer enjoyed Professor E. J. King's chemistry of silicosis in which there is an admirable historical background preceding the experimental aspects, Dr. A. H. T. Robb-Smith's comprehensive account of connective tissue, and Professor Wilson Smith's survey and predictions on virus mutations.

Sir Alexander Fleming contributes an authoritative review on the use and abuse of antibiotics, but it is a pity that he sets a bad example by clinging to the trade-name, chloromycetin.

This is a collection of lectures which will make everyone proud of the contributions of British medicine in a variety of fields and will undoubtedly be an inspiration to further efforts. It is the type of volume which drives readers back to Volume I and makes them look forward to Volume III.

$$
\text { D.G.J. }
$$

\section{RECENT ADVANCES IN DERMATOLOGY}

By W. N. GoldsMith, M.A., M.D., F.R.C.P., and F. F. Hellier, O.B.E., M.A., M.D., F.R.C.P. Second Edition. Pp. $x+46 \mathrm{r}$, with 33 illustrations, five in colour. London: J. \& A. Churchill Ltd. 1954. 42s.

Perhaps it is trite to say that a book of this kind is of value only to the Postgraduate who already has a knowledge of dermatology. The impetus for advance in knowledge of the behaviour of the skin has very often come from workers outside the ranks of clinical dermatologists: hence the value of a book such as this, both to the comparative novice and to the old hand.

The authors have summarized and co-ordinated the most important published work which has appeared since the First Edition, ' paying particular attention to basic physiological and pathological influences in causation, and to rational treatment.'
They have also included short summaries of the salient developments in knowledge of many subjects. These historical summaries are extremely valuable in forming the perspective for recent work.

There can be no hesitation is saying that this is $a$ most valuable book which will be very widely used $\stackrel{\text { ? }}{?}$

As one would expect, the text is clear and concise, without bias or prejudice. Probably any failing $s$ 은 which the book may have can be attributed to the? enormous amount of material that has had to be $\mathbb{Q}$ included. It is 18 years since the First Editiong appeared, so that the authors have been set a hards

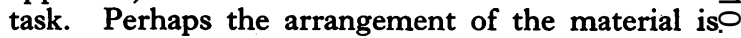
not entirely satisfactory. It might have been more $\overrightarrow{-}$ useful to describe the advances in treatment of tuberculosis of the skin under one heading. Theo use of calciferol is"described in full in the chapter orf vitamins, together with a short mention of the use of - . iso-nicotinic acid hydrazide. Streptomycin is men- $\omega$ tioned elsewhere. The use of I.N.H. might have $\omega$ appeared under tuberculosis in the index.

It is surprising to find no mention of the differen tiation of kerato-acanthoma from epitheliom Although first described in 1936 , it is in recent years that publicity has been given to this still contro-? versial lesion.

However, these adverse criticisms should not detract from the general excellence of the book. 0 Because a book like this, although it may be " white. hot 'at the time it is written, steadily and inevitabsy. becomes out of date, it is hoped that the publisherse will not wait a further eighteen years before produet- $A$ ing the next edition.

TEXTBOOK OF OPERATIVE GYNAECOLOGY

By Wilfred Shaw, M.A., M.D., F.R.C.S., $\overrightarrow{\overrightarrow{0}}$ F.R.C.O.G. Pp. ix +444 , with 383 illustrations, some in colour. Edinburgh: E. \& S. Livingstone? Ltd. 1954. £5.

A search through the shelves of several libraries? fails to reveal any book published in Britain in this. century and dealing with gynaecological surgery 3 that approaches in any way the beauty and the excellence of this gynaecological work.

It is surely the new standard textbook not merely additional to, but replacing most others.

Although Wilfred Shaw was an individualist and $D$ admittedly describes the technique he himself used, most other methods are adequately explained. It $N$ is true that the anatomy of the pelvic floor is in facto still imperfectly worked out, but the description N given in this book is one of the most lucid yet published.

As is to be expected from his special interests the chapter on ovarian surgery too is outstanding, especially the short but brilliant introduction to ito dealing with ovarian pathology.

The whole field of surgical technique is carefully elaborated throughout the book. 